\title{
Uma análise crítica da trajetória de Meira Mattos: Pensamento e ação de um apoiador da Ditadura Civil-Militar de 1964
}

\author{
A critical analysis of the trajectory of Meira Mattos: Thought and \\ action of a supporter of the Civil-Military Dictatorship in 1964
}

\author{
Wanderson Oliveira Coêlho \\ Universidade Federal de Uberlândia (UFU), Uberlândia, MG, Brasil.
}

\begin{abstract}
Resumo: O general Carlos de Meira Mattos figurou como um dos principais pensadores da questão geopolítica brasileira, além de ter sido um ativo articulador do "projeto de Brasil" que se consolidou com o golpe civil-militar de 1964. Em vista disso, o objetivo central desta pesquisa foi reproduzir e analisar, criticamente, o conjunto das ideias elaboradas por Meira Mattos. Para tanto, além de perquirirmos o sentido do conjunto de sua obra individual e os traços constitutivos de sua perspectiva teórica como um todo, centramos a investigação em temáticas que melhor traduziram a finalidade da pesquisa. Simultaneamente, buscamos a compreensão do contexto histórico e social da segunda metade do século XX, no qual demarcamos as disputas ideológicas internacional em suas implicações para a conspiração e o golpe militar de 1964. Por fim, voltamos nossa análise à forma como Mattos deu encaminhamento ao projeto político do governo ditatorial de 1964, dando atenção especial à sua obra geopolítica e sua atuação enquanto ideólogo.
\end{abstract}

Palavras-chave: Meira Mattos. Ditadura civil-militar. Geopolítica.

\begin{abstract}
The General Carlos de Meira Mattos was one of the main thinkers of the Brazilian geopolitical issue, besides being an active articulator of the "project of Brazil" that was consolidated with the civil-military coup in 1964. In view of this, the central objective of this research was to reproduce and analyse, critically, the set of ideas elaborated by Meira Mattos. For this purpose, besides probing the sense of the ensemble of his individual work and the constitutive features of his theoretical perspectives as a whole, we have centralized the investigation in themes that translated better the research's finality. At the same time, we sought to understand the historical and social context of the second half of the twentieth century, in which we demarcated international ideological disputes in their implications for the conspiracy and military coup in 1964. Lastly, we return our analysis to the way how Mattos brought forward the political project of the dictatorial government in 1964, giving special attention to his geopolitical work and his role as an ideologist.
\end{abstract}

Keywords: Meira Mattos. Civil-military dictatorship. Geopolitics. 


\section{Meira Mattos e o Golpe}

O general Carlos de Meira Mattos fez parte de uma geração de militares constituída sob o afã de pensar a questão geopolítica conferindo-lhe status de ciência nacional. Este fato contribuiu para que sua produção teórica, iniciada no final dos anos 1950, se voltasse a ponderar sobre questões que depois se tornaram caras ao regime ditatorial instituído em abril de 1964.

O autor direcionou-se sob uma compreensão pragmática acerca da teoria e da intervenção política. Enquanto militar, envolveu-se decisivamente nos debates “ditados” pelo clima da Guerra Fria, o qual dava a tônica das relações internacionais à época. Já no âmbito do próprio Brasil, preocupou-se sobremaneira com a questão da "potência nacional" e da luta ideológica anticomunista.

Em grande medida devido à sua afinidade com estes fatores, Mattos foi levado a operar junto aos movimentos de conspiração para o Golpe. Ele compreendia as Forças Armadas enquanto instituição responsável por tutelar o Estado a fim de impedir qualquer "atentado à ordem constituída" (MATTOS, 1970). Antes de participar, entretanto, dos processos de desestabilização do governo João Goulart, o general havia estreitado laços com ideias pró-Estados Unidos, iniciadas ainda durante a Segunda Guerra Mundial. Da Escola Superior de Guerra ESG, Mattos recebeu a base teórica sobre a qual firmou sua consciência política, bem como estabeleceu os fundamentos das teorias que passou a desenvolver no terreno específico da divisão geográfica internacional.

Uma vez instaurada a ditadura civil-militar², Mattos não apresentou pudores em exercer mesmo tarefas truculentas ligadas à “necessidade” de consolidação do regime. Aliás, traço característico de seu estilo foi ter se mostrado hábil enquanto homem de ação, ao mesmo tempo em que se dedicava à elaboração teórica. Assim, atuou como representante do novo governo, em sua face efetivamente militarizada, já a partir dos primeiros movimentos no sentido de impor a nova (des)ordem política. Tal postura foi observada, por exemplo, na narrativa dos "primeiros passos" adotados quando do impasse na sucessão governamental:

[...] tropas federais foram movimentadas na direção de Goiânia. E assim, quase que em seguida à concessão do habeas-corpus, o governador Mauro Borges entregava o governo de Goiás ao interventor Meira Mattos.

Consumado o plano, tratou-se de obter sua coonestação pelo Congresso, devidamente coagido com a argumentação de que havia mais uns dez Estados passíveis de sofrer operação análoga. No início de 1965 o coronel Meira Mattos dava por concluída sua tarefa, depois de "reordenar" a política no Estado de Goiás (BEIGUELMAN, 1994, p. 37-38).

De forma similar, em descrição feita pelo deputado Ronaldo Costa Couto a respeito do protagonismo exercido pelo então coronel Meira Mattos na “dissuasão” de um emblemático

\footnotetext{
2 A opção pelo uso do termo civil-militar tem a ver com o fato de [...] "que o ocorrido em 31 de março de 1964 não foi um mero golpe militar. Foi um movimento civil-militar [...]. A elite orgânica, durante a presidência de João Goulart, havia ajudado a conduzir o Estado brasileiro para uma situação em que uma intervenção pelas Forças Armadas poderia ser encarada por um grande número de militares como uma solução adequada para as contradições da sociedade e do governo brasileiro" (DREIFUSS, 2008, p. 419).
} 
“protesto”, na verdade, em face da resistência oferecida pelo Congresso Nacional contra a ditadura, em 1966, apresentou-se o seguinte:

No Congresso, luz e água cortados, o ataque já era esperado. E ninguém tinha a mais remota ideia de resistência armada. Mas, lá fora, o coronel Meira Mattos comanda operação de guerra. Está metido num uniforme de campanha. Usa capacete, cinto de balas e pistola embalada. Cercado de soldados, invade em corrida acelerada o saguão principal. Então vê, de pé no primeiro degrau da escada, que dá acesso ao segundo andar e ao plenário, o deputado Adauto Lúcio Cardoso. Os dois há muito se conheciam. Mas ele ouve: "Alto! Quem é você"? Meira Mattos toma posição de sentido: "Eu sou o poder militar". E ouve: "Pois eu sou o poder civil. Cumpra sua missão, mas saiba que a História o condenará" (BRASIL, 2006, p. 15).

Em algumas outras passagens, escritas por distintos autores com o objetivo de esclarecer os acontecimentos relacionados ao golpe de 1964 e à ditadura que o seguiu, Mattos foi compreendido enquanto personagem despótico, sempre imbuído de tarefas embaraçosas, frente às quais impôs, todavia, ação resoluta direcionada à defesa da "revolução". A atitude do general paulista foi semelhante a de muito homens, militares ou não, que se orientaram mediante o viés golpista, pelo menos desde a renúncia do então presidente Jânio Quadros. Ao ser questionado, em entrevista concedida à TV Câmara, sobre o contexto pré-64, apreciamos o seguinte diálogo entre os entrevistadores e Meira Mattos:

A partir de que momento o senhor participou da conspiração?

- Eu participei da conspiração a partir do momento da renúncia do Jânio. Porque o grande divisor se deu na hora da renúncia do Jânio. Foi com a renúncia do Jânio que apareceu a ala da legalidade, que se dizia da legalidade. E o Brizola era o líder dessa ala, compreendeu? Mas essa ala se espalhou e toda a esquerda brasileira se aliou a ela, compreendeu? E se instalou no Governo João Goulart. O João Goulart, politicamente, havia duas pessoas que o conduziam: um era o Brizola e o outro era o General Assis Brasil - todos de esquerda, tá? E o sonho deles era transformar o Brasil numa república sindicalista. E eles, no governo, promoveram atos sucessivos (BRASIL, 2003, p. 4).

O estabelecimento do plano teórico enquanto suporte ideológico e também como forma de intervenção política foi um traço constante no decorrer da obra de Meira Mattos. Seu entendimento do contexto pré-64, entretanto, não diferiu dos aspectos gerais, cuja estrutura compareceu, sobretudo, na visão do alto comando da "revolução". Tal compreensão, consistia em explicar a necessidade, assim como justificar a profundidade da violência que irrompia quase exponencialmente, consagrada à tarefa de fixar o Golpe.

Devido ao sentido próprio da vida castrense, Mattos deu início à sua atividade política por meio da intervenção prática, sob a voz de comando da hierarquia militar. Apenas depois de 
constituído como militar maduro é que passou a contribuir na condição de intelectual. Isso foi mediado, como facilmente se deduz, devido à vinculação a um posicionamento político de direita.

É necessário notar, porém, que apesar da hegemonia no comando militar brasileiro ter sido quase sempre desempenhada por setores desta agremiação política, houve também constante resistência de uma ala progressista, constituída, inclusive, por soldados adeptos do comunismo. No entanto, uma das questões centrais para o enfraquecimento das disputas foi determinada pelo contexto internacional capitaneado por uma esmagadora presença ianque.

A Segunda Guerra Mundial, como continuação, pelas armas, da concorrência entre as potências capitalistas, submeteu as nações mais fracas à hegemonia dos Estados Unidos. Ocorreu, internacionalmente, o fenômeno da concentração e centralização da riqueza, o processo pelo qual a liberdade de competição, principal mola do progresso capitalista, engendrou o sistema de monopólios [...]. O Brasil, como um país capitalista em desenvolvimento, sentiu todo o impacto da influência americana. A penetração econômica e militar atingiu a superestrutura da sociedade, modificou hábitos e costumes, padrões de comportamento, consciência e linguagem (MONIZ BANDEIRA, 2007, p. 429).

Por outro lado, em que pese a inegável ação imperialista, os militares progressistas tiveram que enfrentar também os erros cometidos pelo próprio movimento nacionalista que, mesmo conquistando vitórias em 1955 e 1961, seguia amargando constantes derrotas, sendo a maior delas, 1964. "O corte de 1964 mudaria de vez a lógica da exceção, tanto no hemisfério da ordem política quanto no dos ilegalismos do povo miúdo e descartável” (ARANTES, 2014, p. 283).

De certo não se pode duvidar da capacidade destrutiva das ditaduras instaladas no Brasil antes de 64, porém, o que se pôs em perspectiva foi a amplitude e simultânea profundidade com que os militares deste último período se lançaram contra a ascensão, por exemplo, dos movimentos sociais. De modo que o "Golpe avançara o derradeiro sinal com a entrada em cena de uma nova 'fúria' - para nos atermos ao mais espantoso de tudo, embora não se possa graduar a escala do horror: a entrada em sena do 'poder desaparecedor"” [...] (Idem, p. 37).

A fúria militarista da qual nos falou Paulo Arantes, obedecia a parâmetros estabelecidos pela evolução da própria luta ideológica internacional resultante da Guerra Fria. “Depois de mandar prender, mandar desaparecer como política de Estado, e tudo que isso exigia: esquadrões, casas e voos da morte. Essa nova figura - o desaparecimento forçado de pessoas - desnorteou os primeiros observadores" (ARANTES, 2014, p. 294). E, mais à frente, complementando a questão: "É bom insistir: foi justamente a capacidade política de organização daquelas 'pessoas comuns' o alvo primordial do arrastão aterrorizante que recobriu o país a partir de 1964" (Ibid., p. 294). Sobre o clima de "bipolarização do mundo" e o peso daquele cenário para o Brasil, em sua implicação no ideário, bem como na ação política militar de esquerda, Paulo da Cunha nos brindou com uma análise do caso exemplar representado por Nelson Werneck Sodré: 
No plano internacional, muito já foi sinalizado sobre o significado combustor da Guerra Fria, que, associada às sucessivas crises internacionais em curso, trazia ao autor e seus camaradas a nítida sensação de que a próxima guerra mundial era uma questão de tempo e, muitas vezes, de dias. O embate enunciado entre as civilizações cristã e ocidental X comunistas justificava, para muitos militares, a influência americana e a dependência nacional, ainda que, para Sodré, o imperialismo fosse a maior ameaça à paz, refletindo-se, no plano interno brasileiro, na submissão, no atraso e no servilismo [...]. Após discorrer sobre o caráter do governo Dutra, as sucessivas companhas em defesa do petróleo e da Amazônia, que eram um fator de atrito com o imperialismo americano, o historiador chama a atenção para os seus aliados internos, como também para as forças que deveriam ser antepostas à resistência (CUNHA, 2001, p. 319-320).

O caminho percorrido pelo general Carlos de Meira Mattos representou o contraponto exato dos compromissos políticos assumidos pelo também militar, Werneck Sodré. O primeiro esteve ligado justamente às forças pró-imperialistas, lutando ao lado da "civilização cristã" contra o que entendia ser o "comunismo ateu”. Desse modo, a concepção teórica na qual ele sustentou a conspiração e o Golpe, deitou raízes nas formulações previamente arquitetadas por instituições como a ESG. Também nesse particular Mattos ajudou a compor o quadro geral dos agentes militares que, após estreitarem laços com soldados norte-americanos durante a Segunda Guerra Mundial, passaram a pregar a doutrina da interdependência, especialmente entre Brasil e Estados Unidos.

Contudo, no campo da esquerda, provavelmente a primeira interpretação, dando conta de que o golpe civil-militar foi capitaneado por setores reacionários da própria sociedade brasileira, veio de Ruy Mauro Marini. ${ }^{3}$ Ele apontou para o fato de que nos momentos imediatamente anteriores, bem como logo depois do golpe, o Brasil não cumpria a função de títere político dos Estados Unidos, tal como era suscitado por parte da esquerda e, inclusive, da imprensa (DINES, 1964).

Na contramão disso, Marini recorreu à análise da correlação de forças e da conjuntura política pré-64 como forma de explicar a conspiração golpista. Mais especificamente sobre João Goulart e a colaboração de classes o autor estabeleceu uma crítica à atuação política do Partido Comunista Brasileiro - PCB, e depois, à posição pequeno-burguesa do governo Goulart. Apontou estes dois elementos enquanto corresponsáveis pela ação da burguesia, classe média, Igreja e por fim dos militares, que puderam deflagrar o golpe e instaurar a Ditadura.

O golpe militar que depôs o presidente constitucional do Brasil, João Goulart, em abril de 1964, foi apresentado pelos militares brasileiros como uma revolução e definido um ano depois por um de seus porta-vozes como uma "contrarrevolução preventiva”. Por suas repercussões internacionais, sobretudo na América Latina, e diante das concessões econômicas aos capitais norte-americanos,

3 "Ainda no Brasil, Ruy Mauro elabora a interpretação mais influente nas novas gerações de militantes sobre as razões do golpe de 1964 e sua inserção no processo de acumulação capitalista no país, que circulou amplamente em várias versões, de forma clandestina [...]" (SABER, 2000, p. 8). 
muitos consideraram o golpe simplesmente como uma intervenção disfarçada dos Estados Unidos. Essa opinião é compartilhada por determinados setores da esquerda brasileira que, no entanto, nunca souberam explicar por que, precisamente quando pareciam chegar ao poder, este lhes foi inesperadamente arrebatado sem que se disparasse um só tiro (MARINI, 2013, p. 73).

Marini pôs maior gravidade na análise do que denominou compromisso político de 1937, isto é, a composição de classes constitutiva do Estado Novo, que arrebanhava os setores agrário e industrial brasileiros, os quais se esforçavam para garantir os interesses tácitos relativos aos setores burgueses. Todavia, estabeleceu que foram exatamente estes os momentos em que a vida política do país foi convulsionada, pois coube a 1954, 1961 e, finalmente, 1964, a responsabilidade de colocar em cheque o referido compromisso. O autor demarcou que o governo Vargas, longe de expressar um caráter revolucionário, em termo de uma burguesia industrial que impõe seus interesses de classe; representou um avanço industrial, porém, tolhido pela conciliação de estruturas sociais que fomentavam a conjugação do historicamente "velho" ao historicamente "novo".

O autor determinou aspectos da "impossibilidade" histórica do desenvolvimento de um capitalismo autentico no Brasil. O que seriam, por um lado, a arcaica estrutura agrária vigente e, por outro, a forte dominação imperialista que regia os rumos político-econômicos do país. Marini apresentou excelente síntese da entrada e dominação do capital imperialista sobre os setores da economia brasileira, desenvolvendo um raciocínio que, após explicar o ambiente de instabilidade dos governos, que por sua vez levaria ao golpe de 1964, explica ao mesmo tempo a posição submissa da burguesia brasileira ao imperialismo.

Igualmente, a influência do Itamarati concorreu para o ajuste da política externa brasileira que passaria, então, sob os auspícios de homens como Vasco Leitão da Cunha, a pregar a subordinação brasileira à diplomacia ianque. Esta seria a forma cada vez mais decantada de explicar a posição ideal a ser ocupada pelo governo frente à grande divisão geopolítica internacional. Alterava-se, por conta disso, os conceitos de guerra e paz predominantes até aquele momento, a fim de se implementar uma ação política que desse vazão às novas exigências da luta ideológica (SCHILLING, 1981).

O quadro conjuntural resultante da Guerra Fria teve pelo menos duas implicações iniciais para o contexto histórico da ditadura civil-militar de 1964. Consequências que tratamos de demonstrar por meio do "resgate" da atuação política e da concepção teórica formuladas pelo general Carlos de Meira Mattos.

Como se pode notar, o primeiro resultado guardou relação com a ordem internacional e consistiu em determinar qual posição geoestratégica o Brasil deveria assumir perante o conflito entre Estados Unidos e União Soviética. E, no plano nacional, engendrava-se o clima político decorrente do primeiro aspecto, criando, dessa forma, as bases para a chamada luta contra o inimigo interno.

Como atitude típica desse contexto, o comportamento político do então coronel Meira Mattos ofereceu-nos elementos para percebê-lo enquanto expressão privilegiada, por um lado, da truculência interna através da qual a ditadura se fazia sentir ao reprimir os focos de 
resistência. E, por outro lado, a política externa alinhada aos interesses dos Estados Unidos, contra as próprias aspirações dos povos latino-americanos:

O Coronel-de-Infantaria Carlos de Meira Mattos, Comandante do Batalhão de Guarda Presidencial, a tropa de choque e de elite de Brasília. É o mesmo coronel que fora a São Domingos com tropas brasileiras para permitir que os dominicanos votassem livremente. O mesmo que deixara o Brasil para defender a democracia. E é o mesmo que desembarca na porta do Congresso Nacional com extremada violência (NETO, 2003, p. 503).

No protagonismo do soldado, forjava-se a consubstanciação do poder que, tomado de assalto da democracia representativa civil, após o golpe de Estado, já não podia mais fazer frente às prerrogativas do domínio militar. ${ }^{4}$ No entanto, a esta realidade, fez-se necessário ainda vincular o novo posicionamento adotado pelas Forças Armadas e seus setores de inteligência, os quais encontravam-se articulados em função do estatuto doutrinário estipulado pela Escola Superior de Guerra - ESG. O papel de Meira Mattos foi, desse modo, orientado pela nova concepção institucionalizada na doutrina de Segurança Nacional, cuja razão de ser deixava de lado o objetivo secular voltado à defesa da pátria, contra um possível inimigo externo, para se concentrar quase que exclusivamente na obsessiva perseguição ao inimigo interno (ALVES, 2005, p. 31).

No processo de instauração da ditadura, esses "princípios doutrinários" passaram a orientar a postura diplomática do Brasil no interior da América Latina. Em decorrência da nossa dimensão geopolítica, os Estados Unidos trataram de encaminhar - juntamente com os militares no poder - a intervenção diplomática ou bélica nos países tidos como "em crise institucional". O primeiro caso foi a invasão de São Domingos pela Força Interamericana de Paz. Sobre sua relação com o processo de estabelecimento da ditadura, bem como com o episódio específico de "pacificação" na América Central, Mattos lembrou o seguinte:

Então, houve a revolução. Em virtude da revolução, o Presidente Castelo me convidou para vice-chefe do Gabinete Militar. Eu era coronel. Então, eu servi no Gabinete Militar até que houve a crise da República Dominicana. Na Crise da República Dominicana, veio um apelo da Organização dos Estados Americanos para que o Brasil integrasse uma força internacional para uma intervenção coletiva. Então, o Castelo me mandou para lá para ver como estava aquilo, para opinar, antes dele tomar uma decisão. Eu fui, opinei e fiquei comandando a força. O Brasil mandou um contingente. Os americanos aceitaram que o comando geral da força fosse brasileiro. Aí tivemos de mandar um general de 4 estrelas para lá, que comandou inclusive os americanos, o general Panasco Alvim. E foi

\footnotetext{
4 "Aberto o dissídio entre o poder militar e o civil representado no Congresso, o governo baixava no dia 20 de outubro o Ato Complementar n. 23 pelo qual era decretado, nos termos do art. 31 do AI-2, o recesso parlamentar até o dia 22 de novembro de 1966. Simultaneamente era promovida uma operação bélica, com tropas chefiadas pelo coronel Meira Mattos (que já atuara em Goiás) ocupando o Congresso" (BEIGUELMAN, 1994, p. 72-73).
} 
organizada uma brigada com todos os latinos que estavam lá, chamada Brigada Latino-Americana, e eu assumi o comando (BRASIL, 2003, p. 5).

Nos anos imediatamente anteriores ao golpe de Estado que depôs o presidente João Goulart, Meira Mattos havia exercido funções como adido militar na Bolívia. Ele escolhera este país devido ao interesse que despertara pela Revolução de 1952, cuja importância lhe causava enorme impressão uma vez que apresentava afinidade direta com os problemas da doutrina de Segurança Nacional, além de significar oportunidade privilegiada (uma espécie de laboratório) para observar e talvez contribuir com a neutralização do "inimigo interno" naquele país. Por dois anos esteve inteiramente imerso à função de observador e participante da política boliviana, constituindo, dessa forma, experiência fundamental que influenciaria na preferência do general-presidente Castelo Branco em enviá-lo, no ano de 1965, à República Dominicana.

Nesse contexto, havia a necessidade de intervir em várias frentes, nas quais a ação era quase sempre direcionada a salvaguardar o caráter "revolucionário" do Golpe, isto é, utilizava-se de todos os meios possíveis com a finalidade de instituir a contrarrevolução. No entanto, este processo figurou no pensamento da elite civil-militar enquanto corolário de uma revolução autêntica, cujas raízes provinham não dos setores dominantes, mas dos anseios do próprio povo que, segundo eles, "exigia" a intervenção militar nas ruas. ${ }^{5}$ Além disso, tanto o golpe quanto a ditadura serviriam a um propósito maior: conter o crescente ânimo da "esquerda" em ascensão e prestes a atingir seu intento de "implantação do comunismo" no Brasil.

Em âmbito precisamente militar, a longa tradição golpista brasileira havia sido crucial ao preparar o terreno político-ideológico propício à ação armada, que culminou no violento 1964. O alto escalão das Formas Armadas, a um só tempo, alinhado aos Estados Unidos e subordinado às exigências da burguesia brasileira, opunha-se ferrenhamente às medidas populares do governo Goulart, ao mesmo tempo que concebia a conspiração generalizada como atitude positiva, até mesmo patriótica, de oposição. A tomada do poder, assim como a instalação do regime ditatorial pela força, colocava em xeque a democracia representativa; em seu lugar, passaria a viger o estado de exceção.

Após a Segunda Guerra Mundial, os golpes militares, no Brasil, apresentam curiosa alternância (e aqui são incluídos os pronunciamentos que não chegaram à fase de luta armada e conquista do poder): em 1945, Vargas é deposto, quando orientava a redemocratização do país, acusado de pender para a solução ‘subversiva'; em 1951, retorna ao poder, garantido pelos militares, em consequência de sua consagração nas urnas; em 1954, é deposto e levado ao suicídio, ao inclinar-se em uma posição nacionalista; em 1955, entretanto, Kubitschek, apoiado em forças políticas antes organizadas por Vargas, tem a posse assegurada pelos militares; em 1961, com a renúncia do presidente Quadros, a tentativa de golpe

5 Em entrevista, Mattos determinou que o advento da "revolução de 64" se deu: "Porque o povo estava nas ruas pedindo a revolução, não sei se você sabe. Não sei se você assistiu ao comício de São Paulo, ao comício do Rio. O povo estava nas ruas pedindo a revolução. Você pode até dizer que o Exército fez a revolução atendendo a um apelo popular veemente" (BRASIL, 2003, p. 6). 
militar aborta por força de resistência da própria força militar. Existe, assim, uma alternância, na sequência dos golpes e pronunciamentos militares: ora eles se definem em defesa de soluções democráticas, ora contra a democracia; têm um sentido em 1951, em 1955, em 1961 e têm sentido oposto em 1945, em 1954, em 1964. Entre 1945 e 1965, menos de vinte anos, os militares no Brasil, depuseram quatro vezes os presidentes (SODRÉ, 1984, p. 27).

Contudo, rejeitando essa leitura, personagens como Meira Mattos entenderam que a única forma de enfrentamento dos problemas brasileiros considerada plausível - de acordo com as medidas organizadas pelo menos desde 1950 e acirradas no decorrer dos anos 60 - consistia na vaga ideia da "integração nacional”. Ela representaria o "progresso modernizador" desencadeado pela "revolução", isto é, uma política comandada pela ditadura civil-militar. Mattos também apontou, insistentemente, para a ideia de que só a "revolução militarista" encaminharia o Brasil a seu destino de grande potência.

Nessa lógica, o contexto daqueles efervescentes anos da vida política brasileira, centrado no período pré-64, foi traduzido por uma chave salvacionista. ${ }^{6}$ Ao apresenta-lo, registrou o seguinte:

Castelo Branco, em 1964, ao receber, surpreso, o governo da Revolução, que mais parecia uma "massa falida", arrasada por três anos de demagogia e de irresponsabilidade administrativa, pôde sentir uma realidade pulsar sob o sufocamento daquela crise - era a de um Brasil com vontade de crescer, com impulso para os grandes desafios, orgulhoso de realizações recentes (a construção de Brasília, a implantação da indústria automobilística, a construção de grandes hidrelétricas, o impulso geral de industrialização), em que fora porta à prova a vontade nacional. Soube Castelo Branco reunir os valores morais, psicológicos, que, para sorte nossa, poderiam ter sido atingidos, mas que estavam apenas dispersos, abalados pelos três anos de insânia que em 1961, 1962, 1963 e começo de 1964 envolveu a nação (MATTOS, 1984, p. 74, grifos nossos).

A ruptura do aparato político-institucional comandada militarmente pelo conjunto das Forças Armadas orientou-se de imediato aos expurgos políticos. Muito em decorrência desse fato, dois elementos afloraram nos discursos dominantes de então: a denúncia da subversão à ordem constituída e a perseguição aos corruptos.

No primeiro grupo eram imputados praticamente todos os indivíduos que, em decorrência dos mais variados motivos, e lançando mão das mais diversas formas, questionavam o status quo. À esta dupla implicação compareceu o autor do qual nos ocupamos neste trabalho, pois, para ele o inimigo central correspondia à "ameaça da subversão”. O general justificou enfati-

\footnotetext{
6 "A usurpação do espaço político da cidadania pelas Forças Armadas tem sido justificado como missão salvacionista, da qual o militar está imbuído. Temos assim um ethos heroico/despojado para os papéis empenhados até agora. Na realidade, o arcabouço ideológico-normativo que informa a pretensa missão salvacionista dos militares e que se expressa na factualidade do golpe de Estado pretende repousar no texto constitucional vigente, que deixa brechas para o princípio intervencionista. Há uma auto-investidura exclusivista do patriotismo, da 'certeza moral' enfim, da autossuficiência ética a respeito de suas próprias ações - assim como um profundo desprezo pela capacidade popular de definir os seus caminhos - e que faz com que a intervenção seja considerada não como um ato de preocupação descabido ou como aberração política, mas como um “imperativo categórico'” (DREIFUSS, 1987, p. 114-115, grifos do autor).
} 
zando que os "comunistas" dedicaram-se incansavelmente à estratégia de seduzir o governo “demagógico", do "inexpressivo" líder político João Goulart, que sedia à pressão da esquerda e encaminhava cada vez mais o projeto de instauração de uma "república sindicalista no Brasil".

A sua explicação correspondia à visão plasmada, pelo menos desde de 1949, quando da fundação da ESG, momento em que se estabeleceu as bases para a "onipotente" Doutrina de Segurança Nacional. Segundo Mattos, estas diretrizes para uma política nacional, formuladas por "homens de grande têmpera", seriam a materialização e, sobretudo, a confluência de objetivos genuinamente brasileiros com os "pressupostos morais inalienáveis" da civilização ocidental. Nesses termos, em 1975, Mattos dava a público sua primeira interpretação acerca do vínculo orgânico entre doutrina esguiana, golpe e ditadura civil-militar:

Em 1949, com a criação da Escola Superior de Guerra, o pensamento político brasileiro começou a se estruturar em bases realísticas e científicas. É a ESG responsável por uma doutrina política essencialmente brasileira, fundamentada na dinâmica da aplicação do poder nacional. Assentada na relação de mútua causalidade entre Segurança e Desenvolvimento, a doutrina difundida pela ESG durante mais de um quarto de século fundamenta-se essencialmente, no levantamento dos objetivos nacionais permanentes e objetivos nacionais atuais, e na formulação de uma política para alcançá-los.

De 1949 a 1964, durante 14 anos, a ESG não teve influência maior nas decisões do governo. Entretanto, formulou sua doutrina de segurança nacional e pesquisou profundamente no campo do desenvolvimento. Formou elites civis e militares aptas a pensar o Brasil com objetividade [...]. Quando veio a Revolução de 1964, a doutrina da Escola Superior de Guerra já estava formulada e exercida em termos laboratoriais ou escolares. Foi fácil para o chefe da revolução, o presidente Castelo Branco e seus principais assessores, Golbery, Ernesto Geisel, Juarez Távora, Cordeiro de Farias, todos ex-militares, participantes ativos na formulação da doutrina, pois todos haviam pertencido aos quadros da ESG, transferirem para a prática governamental a doutrina formulada durante 14 anos no casarão do Forte São João (MATTOS, 2011a, p. 144-145).

No entanto, a visão de mundo encerrada no conjunto da "militância" golpista, seja em plano teórico ou mesmo na sua implicação prática, não expressava diretamente a ideia de que ele foi orientado como um “movimento de salvação nacional”. Esta formulação foi concebida após o evento e passou a figurar como uma espécie de narrativa oficial sobre a tomada do Estado pelos militares - não obstante, é claro, ao tom sempre alarmista expresso no anticomunismo generalizado, pauta que pelo menos desde 1935 arrebanhava os vários setores da direita (D'ARAUJO; SOARES; CASTRO, 1994). Meira Mattos foi um dos primeiros a descrever 1964 enquanto "resultado lógico" do cenário internacional capitaneado pela Guerra Fria, ao mesmo tempo como um movimento político-militar de base civil e responsável por impedir que o país fosse tomado pelo iminente "imperialismo soviético" (RAGO FILHO, 1998).

Pautado sobre este tipo de entendimento, Mattos pretendeu conjugar o repertório analítico já cristalizado no interior da ESG ao novo contexto de Golpe em curso. Com esta operação 
discursiva o autor procurou explicar, a partir de seu campo de estudos, em que grau e qual o sentido da vinculação entre a "Revolução de Março" e as disputas ideológicas internacionais. Em complemento a isso, refletiu sobre como deveria ser encaminhada, uma vez vitoriosa a conspiração e o Golpe, a luta secular por um desenvolvimento modernizador, que englobasse todas as esferas do terreno social.

\section{O projeto de poder da Ditadura}

1964 foi um marco na vida militar e na produção intelectual de Meira Mattos. Mais do que em qualquer outro momento de sua trajetória, o golpe Civil-Militar o projetou politicamente a um caminho que confirmou sua consolidação como uma das figuras mais expressivas do regime em sua área de atuação. Ele pertenceu ao que seria consolidado como grupo da Sorbonne, ou castelista, não só devido a aproximação prévia, firmada com Castelo Branco nos anos imediatamente anteriores ao Golpe, mas sobretudo porque daí em diante Mattos se encaminhou à elaboração intelectual constante.7

A outra parte da contribuição teórica desenvolvida por ele, guardou estrita relação com o ideário geopolítico brasileiro, de tal modo que seria correto situar este elemento como o principal objetivo perseguido pelo autor. Colocou, então, sua atividade acadêmica à disposição da burocracia estatal conforme se afastou do comando direto em operações militares.

A partir daí, e principalmente quando passou à reserva em 1977, sistematizou seu pensamento sobre o Brasil especializando-o num dos ramos dos estudos militares e da geografia. Atingiu depois uma das mais altas patentes, coroando a opção política pelo regime que havia incorporado desde a conspiração, até a instauração da ditadura.

Ao fim do processo, havia se dedicado integralmente à construção do projeto político 1964, o qual entendeu como única solução aos dilemas nacionais.

[...] prosseguimos no afã incansável de modernizar a sociedade brasileira, completando a obra de renovar o sistema de ensino, os processos de produção e os meios de serviços, buscando essa modernização nos seus aspectos político, econômico, social, educacional e cultural. No político, procurando os níveis de participação, de organização e de benefícios sociais, por meio do progresso social e tecnológico; no econômico, lutando pelo crescimento constante do produto interno bruto e do per capita, por uma melhor distribuição de renda e pelo emprego de uma tecnologia cada vez mais avançada; no social, intentando estabelecer padrões de organização geral e social que correspondem à expansão dos benefícios da urbanização a todas as áreas e a uma mudança de valores das profissões, resultante do aumento de especialização e oportunidades de distribuição; na educação, ampliando as oportunidades de ensino a

\footnotetext{
7 "Meira Mattos é considerado um integrante do 'grupo da Sorbonne', constituído por militares, sobretudo do Exército, educados nos Estados Unidos ou na França e que se destacaram por suas habilidades intelectuais. Eles foram responsáveis pela construção do substrato teórico que norteou as ações estratégicas dos Governos do Regime Militar. Esse grupo caracterizou-se por seu ferrenho anticomunismo, com adesão aos princípios da economia privada e da democracia representativa” (VIEIRA, 2005, p. 120).
} 
todos os brasileiros, de todas as partes do território, melhorando a qualidade do ensino, incrementando a pesquisa, adequando o sistema às necessidades políticas, econômicas e sociais do país, disseminando conhecimentos teóricos e técnicos, de sorte a difundir a todos a atividade, a crença na racionalidade; no cultural, estimulando o espírito nacional no cultivo das ciências e das artes, no estudo e na fé nos valores essenciais de nossa história e nossa civilização de raízes cristãs e democráticas (MATTOS, 2011, p. 26-27).

Um traço comum aos ideólogos do regime instituído em abril de 1964 foi conferir ao crescimento econômico o status de fator sine qua non para a sobrevivência do próprio poder ditatorial e, sobretudo, como força impulsionadora do projeto de Brasil moderno subjacente a toda propaganda governamental. Cada pensador, burocrata ou político ligado ao regime, esforçou-se por diversos meios para dar vasão às ideias consagradas como "desenvolvimentistas".

Ao acompanharmos o ideário de Meira Mattos, notamos que ele não se escusou, também, de contribuir nesse empenho comum aos intelectuais orgânicos do regime. ${ }^{8} \mathrm{O}$ autor auxiliou apontando para as possibilidades de "evolução" do Brasil que resultariam, em última instância, na sua conversão ao patamar de potência mundial.

Nesse sentido, ao lançar mão de um diagnóstico da sociedade, a fim de apontar em seguida suas recomendações, o autor iniciou a primeira análise submetendo "o Estado brasileiro ao 'raio X' de Kjellen", como ele mesmo denominou. Se perguntava, nesse momento, a respeito do estado de evolução apresentado por fatores como a geografia, a coesão interna e até mesmo sobre condicionantes climáticos aos quais o Brasil estava sujeito.

Acerca deste parâmetro inicial, apontou que segundo o "critério geral dos estudiosos da geografia humana, a zona tropical é a mais desfavorável ao surgimento das grandes civilizações”. Isso, devido ao "fato" de que nessas áreas “a fixação humana e a valorização econômica do solo constituem, ainda, um desafio da natureza ao engenho do homem" (MATTOS, 2011a, p. 36). Por outro lado, disse o autor:

Esse critério dos antropogeógrafos não é absoluto. Há condições que neutralizam os efeitos negativos da latitude tropical: uma delas é a altitude do solo. Se é verdade que nos trópicos, nas altitudes baixas, preponderam as condições climáticas desfavoráveis, elevando-se estas altitudes transformam-se as condições mesológicas, favorecendo as condições de vida.

Esse fator altitude, no caso brasileiro, veio influenciar favoravelmente. O planalto brasileiro cobre a maior parte do nosso território, propiciando altitudes favoráveis à neutralização dos fatores negativos da climatologia tropical (em

\footnotetext{
8 [...] "um novo conjunto de agentes sociopolíticos aparecia na economia e na política brasileiras. Esses agentes formaram um aparelho civil e militar modernizante responsáveis pelos assuntos relativos à produção e administração política do bloco econômico multinacional e associado. Esta estrutura de poder político de classe do bloco multinacional e associado era corporificada numa intelligentsia empresarial. Esses agentes sociais modernizantes-conservadores, todos eles verdadeiros intelectuais orgânicos do novo bloco em formação, eram: a) diretores de corporações multinacionais e diretores e proprietários de interesses associados, muitos deles com qualificação profissional; b) administradores de empresas privadas, técnicos e executivos estatais que faziam parte da tecno-burocracia; c) oficiais militares" (DREIFUSS, 2008, p. 78).
} 
média cada 180 ou $200 \mathrm{~m}$ de altitude representam o decréscimo de temperatura de $\left.1^{\circ} \mathrm{C}\right)($ Idem).

Contrapondo-se ao determinismo de alguns geógrafos o autor abriu mão, porém, da coerência, para empregar outras formas de determinação - nesse caso uma espécie de determinismo climático - quando resolveu defender, e devido ao modo como o fez, a tese de que os trópicos eram também propícios ao desenvolvimento de grandes civilizações. Ao seguir esta linha de raciocínio, o ponto central seria comprovar que, apesar dos problemas, não havia impedimento natural (geoclimático) que desautorizasse a ascensão do Brasil à categoria de potência.

Toda a primeira parte da obra foi dedicada a apreciações desta natureza, de modo que Mattos estabeleceu um caleidoscópio de exemplos, dados a comprovar que nas várias sub-regiões brasileiras predominavam “condições ambientais ótimas”. Frente a impossibilidade de listar todos os exemplos, citamos o caso típico:

Na Amazônia, em que pese a sua fraca densidade demográfica, fomos capazes de levantar duas cidades do tipo Belém e Manaus (com 400 mil e 250 mil habitantes), o que representa um esforço de que não há exemplo em nenhuma outra área continental equivalente, situada em plena faixa equatorial. Assim, nossa posição, se não é excelente, pode ser considerada boa. E, o que é mais importante - os esforços e engenho de nossa gente provam que não há, em nosso território, áreas de valor socioeconômico inteiramente inútil (Ibid., p. 37).

Essas exemplificações procuravam articular um esforço de compreensão estrutural da realidade geopolítica brasileira como exigência básica para que, em um momento subsequente, fosse possível formular a síntese de seus problemas. "Segundo o critério geopolítico, a medida da força emanante do território de um Estado depende da conjugação de cinco fatores: extensão, posição, articulação, povoamento e possibilidades econômicas” (Ibid., p. 35).

Nesses termos, os elos mais fracos da cadeia nacional seriam, respectivamente, a integração e o desenvolvimento. $\mathrm{O}$ fato de o país apresentar diferenças climáticas, geográficas e, sobretudo, desigualdades sociais flagrantes, distribuídas em vasta área territorial, representava um dilema cuja solução era tida como passo vital para o desenvolvimento das potencialidades nacionais. Não por acaso, desde o fim dos anos 1950, Mattos apresentava a integração nacional enquanto objetivo político definidor de seu ideário. Muito provavelmente, análises similares a essa serviram como pano de fundo ao lançamento dos "Objetivos Nacionais" da ditadura:

A formulação da doutrina política da Revolução baseou-se, fundamentalmente, na eleição e no estabelecimento de uma estratégia para alcançá-los [os objetivos] ou preservá-los. Entre os nove Objetivos Nacionais eleitos

- Independência,

- Soberania,

- Integração Territorial,

- Prestígio Internacional,

- Integração Nacional 
- Prosperidade nacional,

- Democracia,

- Preservação dos Valores Morais e Espirituais da Nacionalidade,

- E Paz Social,

dois foram considerados objetivos-críticos, - Integração Nacional e Prosperidade Nacional - e para sua consecução foi montada a Política de Desenvolvimento. [...] os alvos principais da antirrevolução e da subversão, mereceram o conceito de objetivos a defender, e passaram a constituir a principal preocupação da Política de Segurança (MATTOS, 1970, p. 38-39, grifos do autor).

Desse modo, as perspectivas do projeto ditatorial foram estabelecidas de maneira pragmática, pondo todas as necessidades da esfera social à mercê do imperativo político "revolucionário" em processo de instauração. Como um dos impulsionadores desse projeto, o discurso geopolítico de Mattos buscou, por muitos meios, a justificativa "científica" das prerrogativas inerentes ao "novo" modelo de "desenvolvimento" e de "segurança".

Assentada a ideia de que nossa localização geográfica não desautorizava o projeto de "Brasil grande" (caso fossem implementadas as exigências "técnicas" para tanto), teve lugar o empenho do general no sentido de compor uma outra visão de conjunto, agora voltada à explicação dos revezes históricos nacionais. Mattos se voltou a isso deixando claro a necessidade de transformação do contexto social no qual estava inserido.

Ademais, atribuía constantemente o papel de destaque na condução das mudanças às "elites dirigentes". O autor enxergava a questão nacional determinada, sobretudo, por dois momentos da formação histórica do Brasil: o primeiro, circunscrito às implicações e à necessidade de romper com a ideologia colonialista imposta pelos europeus e o segundo momento, dinamizado pelo dilema, que ascendeu no início do século XX, entre as opções de uma vocação brasileira essencialmente agrícola, versos o empenho inequívoco para o ascenso industrial.

A mentalidade colonialista, dominante entre os políticos europeus, pretendia, em nome do liberalismo econômico e sob o pretexto de racionalização da produção mundial, impor, às áreas dos outros quatro continentes - América, Ásia, África e Oceania -, uma economia do tipo produtor de matérias-primas e consumidor de produtos acabados.

A Europa, durante todo o século XVIII, XIX e parte do XX, foi o principal centro de irradiação cultural do mundo moderno. As ideias europeias eram, via de regra, absorvidas avidamente pelas elites americanas, que se orgulhavam de defendê-las em seus países [...]. Sob a influência quase inapelável dessas ideias, nasceram, cresceram, formaram-se e vieram a atuar, no cenário político nacional, os nossos jovens das gerações do século passado e das primeiras décadas deste século [...]. Tão impregnados deste espírito "made in Europe" andavam as nossas elites, que elas mesmas proclamavam, aos quatro ventos, talvez patrioticamente e sinceramente, embora ingenuamente, o slogan - O 
Brasil é um país essencialmente agrícola. Essa frase não é uma afirmação, como a muitos pode parecer. Ela encerra, dialeticamente, uma negação que assim se poderia traduzir - o Brasil jamais poderá ser um país industrializado (MATTOS, 2011a, p. 49).

A reconstituição histórica deliberadamente pautada pela evolução das "elites dirigentes", tanto a nível mundial, quanto nacional, expôs os parâmetros ideológicos determinantes da compreensão de Meira Mattos, e, de outro lado, o âmbito político sobre o qual ele procurou influir. Aí também se revelou seu entendimento quanto à forma mais progressiva de transformação econômica; por fim, acabou explicitando - mesmo a contragosto - a qual classe seu pretenso nacionalismo esteve subordinado. Através desta narrativa, pretendeu formular, portanto, uma proposta a um só tempo enérgica e didática, servindo como um "plano de conduta" para a "elite" contemporânea, que podia enxergar no relato da vivência de seus predecessores, os equívocos outrora cometidos, a serem, obviamente, evitados.

Contudo, para além de exortar os jovens de sua geração a agir de maneira crítica frente a "ideologias exógenas”, Mattos apostava na ação direta de homens como Roberto Simonsen - exemplo a ser seguido pois conjugava qualidades intelectuais, políticas e empresariais muito raras em sua época. Para o general, impunha-se como tarefa superior, [...] “criar uma 'cúpula mental' orientadora de todos esses esforços renovadores, visando despertar as energias nacionais e projetar o país para a grandeza, (frente a isso) foi criada, em 1949, a Escola Superior de Guerra” (Ibid., p. 54).

A EGS foi entendida, assim, enquanto substância concreta do pensamento que proclamava a necessária renovação das "elites nacionais" em todos os espaços da sociedade. Em seus traços particulares ela representou a conquista desse objetivo no âmbito das Forças Armadas. Por isso, como membro, inclusive por reinvindicação, da Sorbonne, Mattos propugnava a conjugação dos objetivos militares a uma visão de mundo estabelecida pelo pensamento conservador.

Apesar de seu teor abstrato, as teses instituídas pela Doutrina de Segurança Nacional pretendiam, quase sempre, uma visão histórica dos problemas brasileiros. Foi assim com a explicação acerca do caráter e sentido do golpe civil-militar de 1964, que apareceu por vezes sustentado em uma visão filosófica do processo. ${ }^{9}$

Para alguns ideólogos do regime, entretanto, a "filosofia da Revolução" foi muito mais articulada por questões políticas, pois os parâmetros filosóficos faziam parte apenas de discussões éticas, mais ligadas à opção pela "democracia” enquanto forma de governo. Por outro lado, no discurso oficial: ditadura se apresentava como democracia e violência, enquanto meio edificante de segurança e de desenvolvimento. Lançava-se mão, portanto, de eufemismos,

9 [...] "os ONP (Objetivos Nacionais Permanentes) estão mais localizados no campo da filosofia, informadora de uma visão do real, do que no domínio das relações de força política. Pois trata-se de uma visão abrangente sobre o caráter nacional, dos atributos que qualificam o povo por oposição às elites: individualismo, adaptabilidade, improvisação, vocação pacifista, cordialidade, emotividade e criatividade. Estas características são de fato expressões de uma visão de mundo que é a própria da DSN (Doutrina de Segurança Nacional). Esta visão de mundo comporta uma visão jurídico-administrativa do Estado, concebido como um organismo e instrumento de poder [...]. Uma visão organicista e funcional da sociedade [...]. Uma teoria quantitativa do poder, estatal por natureza, que pode ser potenciado mediante aplicação de recursos, visto que ele não deriva de relações sociais. Uma visão estratégica (Brasil-potência) erigida sobre um processo de desenvolvimento (capitalista transnacionalizado) sob a direção da elite civil-militar” (OLIVEIRA, 1987, p. 167). 
quando não da própria mistificação explícita, porém traduzida por uma áurea de despotismo ilustrado.

Tentando uma interpretação filosófica da Revolução de 31 de março, nos idos de 1965, por ocasião do seu primeiro aniversário, chegamos à conclusão que precisávamos muito mais de nos fixarmos numa doutrina política do que nos estendermos em especulações sobre sua filosofia. Isso porque, não havia na liderança revolucionária naquela época, como não há hoje, nenhuma voz discordante sobre a filosofia democrática da Revolução. Fizemos a Revolução para, dentro da concepção de vida democrática, dentro de uma estilo essencial democrático, dentro de uma moral e uma ética democrática, erigimos uma sociedade desenvolvida, superando todos os fatores adversos oriundos de nosso gigantismo geográfico e de nosso atraso socioeconômico (MATTOS, 1970, p. 37).

O general Mattos atribuía, constantemente, ao pragmatismo o sentido e a característica principal da ação política. Ele era leitor assíduo e se considerava "discípulo" de autores como Oliveira Vianna, Alberto Torres e, sobretudo, Golbery do Couto e Silva, figuras reconhecidamente avessas ao liberalismo (RAGO FILHO, 1998). No seu caso particular, as considerações a respeito do Estado, do sistema político e do comportamento social, certamente obedeceram a uma exigência de época. Não era interessante ao general, que se entendia como moderno apoiador do "mundo livre", opor-se a conceitos fundamentais como "democracia" e "liberalismo", uma vez que em sua generalização esses termos poderiam atender a um amplo espectro ideológico (ASSUNÇÃO, 1999).

Para o autor, a questão primordial não tinha a ver apenas com as imposições da "democracia enquanto valor moral imprescindível", como queriam, segundo ele, os norte-americanos. Para além disso, urgia resolver problemas concretos, que se impunham e implodiam teorizações abstratas, isto é, as "exigências verdadeiramente brasileiras" as quais emergiam subitamente em momentos de "ardor revolucionário" e superavam qualquer receituário filosófico-político. Tal como no contexto de 1964, quando declarou:

O fato de sermos democratas, de nossa Revolução ser democrática, apenas, não nos fornece o instrumental para imprimir um rumo político ao governo revolucionário. É a democracia uma ideologia de teto e não um instrumento de ação política. Comparando, diremos que a democracia, assim como o marxismo-leninismo e o nacional-socialismo, aquecem as mentes, mas são insuficientes para mover, desembaraçadamente, as pernas e os braços. O fato de sermos todos democratas, portanto, não nos dá a força motora indispensável à realização de uma obra política revolucionária. Foi o ex-Presidente Castelo Branco buscar as bases de formulação da doutrina política revolucionária nos laboratórios da Escola Superior de Guerra, onde ele já militara, centro de estudos políticos e estratégicos que desde 1949 vinha com seriedade e critério científico procurando formular as linhas mestras de uma política nacional à altura dos mais altos interesses e aspirações nacionais (MATTOS, 1970, p. 38). 
Assim, trava-se de conferir "brasilidade" à resolução da questão nacional, atentando para o fato de que os órgãos de inteligência internos - ligados desde sempre ao status quo e depois à ditadura - desenvolviam ferramentas políticas próprias, embora pensadas no "espírito cristão ocidental”. A essa explicação não ocorria, entretanto, levar em conta o fato de que órgão como a ESG, ou o complexo IPES-IBAD ${ }^{10}$ contavam com amplo suporte ideológico, político e financeiro internacionais, especialmente vindos dos Estados Unidos.

\section{Considerações Finais}

Como se pôde depreender da análise circunscrita ao ideário de Meira Mattos feita ao longo do trabalho, vimos que o autor direcionou esforço intelectual, ao mesmo tempo que se empenhou a um projeto político, para o qual o próprio pensamento acadêmico deu suporte. Isto é, ele funcionalizou sua produção teórica à luta política.

Dessa forma, procuramos localizar no contexto social marcado pela ditadura civil-militar de 1964, o momento preponderante desta conjugação de forças que levou Mattos à preocupação com o andamento da política nacional. Ademais, foi nosso objetivo perceber, no decorrer da pesquisa, os traços constitutivos do ideário em questão, tendo como parâmetro estruturante a noção de que o processo histórico se faz por caminhos tortuosos e que a política é o âmbito social do conflito (VAISMAN, 2010).

O autor foi contemporâneo das tensões provocadas pelo ambiente do pós-guerra e da chamada bipolarização do mundo com a Guerra Fria, mesmo contexto em que começou a publicar, sistematicamente, no final dos anos 1950. Sua experiência como integrante do corpo de soldados da Força Expedicionária Brasileira - FEB, durante a Segunda Guerra Mundial, representou um marco para sua orientação político-ideológica, que se manteve ativa no conturbado processo histórico nacional correspondente, mais ou menos, ao fim do segundo governo Vargas, e daí em diante.

Do ponto de vista da formação histórica do Brasil, o contexto relativo à vida política do autor corresponde aos impactos da definitiva consolidação do país enquanto nação capitalista industrial. Como vimos, Mattos era entusiasta da industrialização, do sistema capitalista e do alinhamento político internacional sob a influência dos Estados Unidos, contra a União Soviética. Nesta quadra histórica, o autor tratou de explicar (à sua maneira) a opção pelo "mundo cristão livre", expressando uma visão de conjunto elitista e comprometida com a manutenção do status quo (MATTOS, 2011c).

Cabe demarcar, entretanto, que a "visão de mundo" relativa ao pensamento do autor, inevitavelmente, se chocava com o sentido das violentas transformações conjunturais centradas na década de 1950. Embora, tais alterações não pretendiam (pelo menos não de forma hegemônica) a mudança do sistema político vigente.

10 Respectivamente, Instituto de Pesquisas e Estudos Sociais e Instituto Brasileiro de Ação Democrática. 
Assim era que, em âmbito essencialmente econômico, a aceleração do processo industrial, determinada pela consolidação dos produtos voltados ao consumo particular e a implementação da indústria de bens de capital, se perfilava como a ponta de lança do avanço que atingia todas as esferas sociais, bem como todas as regiões brasileiras, variando apenas na intensidade do impacto. Esse foi, portanto, um período de intenso crescimento econômico, porém, envolto em uma crise perene:

A crise do fim do período, que por sua vez vai dar lugar à recessão que se lhe segue até o ano de 1967, é uma crise extremamente complexa. Em primeiro lugar, deve-se dizer que as presidências Quadros e Goulart na verdade foram prisioneiras da crise que começou a detonar no último ano da Presidência Kubitschek [...]. O período Goulart intenta uma política econômica, [...] cuja essência consistia na preparação e implementação de uma recessão atenuada, para corrigir as já elevadas pressões inflacionárias; esse caráter contraditório da política econômica, de um lado visando restabelecer as condições do cálculo econômico e, portanto, da continuidade do processo de acumulação de capital, e, de outro, não podendo penalizar as classes trabalhadoras de onde retirava seu apoio político, vai levar à falência toda a política econômica, e não apenas ela: também o regime democrático (OLIVEIRA, 1984, p. 90-91).

O surto de crescimento apresentado pelo setor industrial, que passava ao comando da dinâmica produtiva, indubitavelmente se efetivou; porém, gestando em seu interior a "crise de realização", o "estrangulamento cambial”, a "fuga de divisas”, entre outros problemas dos quais se ocuparam autores como Oliveira (1984). Deste modo, constituiu-se uma explicação essencialmente econômica e simultânea, para a consolidação da indústria nos anos 50 e os impasses governamentais que levariam ao golpe, em 1964.

Todavia, como procuramos demonstrar, Mattos formulou outro tipo de suporte analítico para dar conta dos problemas nacionais, os quais também eram compreendidos por ele na configuração de uma crise social profundamente sensível no pré-64. Entendia que isto se expressava não nas impossibilidades históricas de nossa "herança colonial", nas investidas do imperialismo e mesmo na brutal desigualdade brasileira, mas em âmbito moral, e que tal situação tendia ao "aviltamento da ordem constituída" por um "iminente risco" de implantação da tão propagada "república sindicalista no Brasil" ou ainda, num sentido mais amplo, justificava o uso de um golpe militar como forma contundente de pôr fim à "corrupção generalizada".

Enfim, mesmo indo contra a explicação predominante sempre que se teve liberdade de expressão no Brasil, de acordo com Meira Mattos, os parâmetros gerais expressos na teoria e ação da ditadura civil-militar de 1964 representaram as verdadeiras aspirações nacionais. O general foi taxativo em considerar o período pré-64 como a vigência de uma verdadeira "insânia esquerdista” que ascendia dos movimentos sociais, partidários e políticos em geral, os quais penetravam conscientemente no governo João Goulart. De modo que, no pensamento de Mattos, não houve lugar à dúvida do risco de que o Brasil viesse a enveredar pela senda da subversão, por meio da definitiva implantação de uma "grande Cuba" no coração da América do Sul. 
Em âmbito especificamente historiográfico, conforme a passagem das décadas do golpe de 1964, ganham fôlego discussões em torno do caráter da ditadura. Primeiramente partindo da crítica à ideia de "revolução de 1964" - como os próprios militares entenderam seus feitos - alguns historiadores passaram a qualificar o processo de conquista do poder, bem como de instalação da ditadura militar enquanto um complexo de relações civis e militares. Esse foi o caso, por exemplo, do livro organizado pelo historiador fluminense Demian Bezerra de Melo, cujo escopo revela a estreita relação de importantes setores da sociedade civil com as Forças Armadas no contexto do golpe de 64.

René Dreifuss pensou com Gramsci, ao investigar o golpe de estado de 1964, que não era apenas um golpe militar, e que não apenas envolvia "civis", isto é, não militares, mas entidades empresariais ricas e com apoio internacional. Foi um golpe de Estado estimulado, preparado e com apoio de intensa organização empresarial, que tem nome endereço, documentos e, mais do que isso, forneceram os quadros que ocuparam os postos-chave da reorganização econômica e política após 1964 (FONTES, 2014, p. 14).

Esse tipo de caracterização põe em perspectiva a base social de sustentação do regime instaurado em 1964. No entanto, historiadores como Marcos Napolitano problematizam mesmo a ideia de uma interação "equilibrada” em ter militares e civis, ou ainda com predominância destes últimos.

Mirando os comunistas, os golpistas de 1964 varreram o reformismo da agenda política brasileira. A coalizão antirreformista saiu vencedora, enquanto a coalizão reformista de esquerda foi derrotada. Entretanto, não endosso a visão de que o regime político subsequente tenha sido uma "ditadura civil-militar" ainda que tenha tido entre os seus sócios e beneficiários amplos setores sociais que vinham de fora da caserna, pois os militares sempre se mantiveram no centro decisório do poder (NAPOLITANO, 2014, p. 13).

No interior desse debate, percebe-se, ao mesmo tempo, uma crítica às formas dominantes de entendimento do conteúdo político da ditadura e contribuições no sentido de esclarecer o significado histórico do golpe de 1964, bem como da ditadura que o seguiu. No presente artigo, procuramos compreender um personagem central daquele momento de efervescência política, Meira Mattos, que pertenceu à esfera militar e esteve nas fileiras dos que defenderam o regime até o fim.

\section{Referências}

ALVES, Maria Helena Moreira. Estado e oposição no Brasil (1964-1984). Bauru - SP: Edusc, 2005. ALVES, Hermano. Tempos anormais. Política Externa Independente, Rio de Janeiro: Civilização Brasileira, n. 2, 1965.

ARANTES, Paulo Eduardo. O novo tempo do mundo: e outros estudo sobre a era da emergência. São Paulo: Boitempo, 2014. 
ASSUNÇÃO, Vânia Noeli Ferreira de. O satânico doutor Go: a ideologia bonapartista de Golbery do Couto e Silva. Mestrado em Ciências Sociais. PUC-SP, 1999.

BEIGUELMAN, Paula. O pingo de azeite: a instauração da Ditadura. 2. ed São Paulo: Perspectiva, 1994.

BRASIL. Câmara dos Deputados. Entrevista com o General Carlos de Meira Mattos. Brasília: Câmara dos Deputados, 2003. https://doi.org/10.26512/2005.11.tcc.504

BRASIL. Câmara dos Deputados. Parlamento e a história recente do país (Ronaldo Costa Couto). Brasília: Câmara dos Deputados, 2006. https://doi.org/10.26512/2015.12.d.19795

CUNHA, Paulo Ribeiro Rodrigues da. A utopia tenentista na construção do pensamento marxista de Nelson Werneck Sodré. Doutorado em História. UNICAMP, Campinas, 2001.

D'ARAUJO, Maria Celina; SOARES, Glaucio Ary Dillon; CASTRO, Celso. Os anos de chumbo: a memória militar sobre a repressão. Rio de Janeiro: Relume-Dumará, 1994.

DINES, Alberto. Os Idos de março e a queda em abril. Rio de Janeiro: Editora José Álvaro, 1964.

DREIFUSS, René Armand. 1964, a conquista do Estado: ação política, poder e golpe de classe. 7. ed. Petrópolis-RJ: Vozes, 2008. https://doi.org/10.22201/cela.24484946e.1987.3.46929

FURTADO, Celso. A pré-revolução brasileira. Rio de Janeiro: Fundo de Cultura, 1962.

FONTES, Virgínia. Prefácio. In: MELO, Demian. A miséria da historiografia: uma crítica ao revisionismo contemporâneo. Rio de Janeiro: Consequência, 2014.

MATTOS, Carlos de Meira. Geopolítica. Rio de Janeiro: Editora FGV, 2011a. v. 1.

MATTOS, Carlos de Meira. Geopolítica. Rio de Janeiro: Editora FGV, 2011b. v. 2.

MATTOS, Carlos de Meira. Geopolítica. Rio de Janeiro: Editora FGV, 2011c. v. 3.

MATTOS, Carlos de Meira. Uma geopolítica pan-amazônica. Rio de Janeiro: Biblioteca do Exército, 1980.

MATTOS, Carlos de Meira. Geopolítica e Trópicos. Rio de Janeiro: Biblioteca do Exército, 1984. MATTOS, Carlos de Meira. Doutrina política de potência. In: RENAUT, Abgar et al. (org.). Revolução, evolução. AERP, 1970.

MARINI, Ruy Mauro. Subdesenvolvimento e revolução. Florianópolis: Insular, 2013.

MONIZ BANDEIRA, Luiz Alberto. Presença dos Estados Unidos no Brasil. Rio de Janeiro: Civilização Brasileira, 2007.

NAPOLITANO, Marcos. 1964: História do regime militar brasileiro. São Paulo: Contexto, 2014. https://doi.org/10.18223/hiscult.v3i2.1153

NETO, Casimiro. Quinta República. A construção da democracia: síntese histórica dos grandes momentos da Câmara dos Deputados. Brasília: Biblioteca da Câmara, 2003. https://doi. org $/ 10.26512 / 2005.11 . t c c .504$

OLIVEIRA, Eliézer Rizzo de (org.). As forças armadas no Brasil. Rio de Janeiro: Espaço e Tempo, 1987.

OLIVEIRA, Francisco. A economia da dependência imperfeita. Rio de Janeiro: Graal, 1984.

RAGO FILHO, Antonio. A ideologia 1964: os gestores do capital atrófico. Tese. (Doutorado em História) PUC São Paulo, São Paulo, 1998. 
SABER, Emir (org.). Dialética da Dependência: uma antologia da obra de Ruy Mauro Marini. Petrópolis - RJ: Vozes, 2000.

SCHILLING, Paulo. O expansionismo brasileiro: a geopolítica do general Golbery e a diplomacia do Itamarati. São Paulo: Global, 1981.

VAISMAN, Ester. A ideologia e sua determinação ontológica. IN: Verinotio, revista on-line, n. 12, ano VI, out./2010.

VIEIRA, Friederick Brum. Matrizes teóricas da geopolítica brasileira: as contribuições de Travassos, Golbery e Meira Mattos. Mestrado em geografia. UERJ, 2005.

Recebido em: 16/05/2019

Aprovado em: 30/10/2019

\section{Wanderson Oliveira Coêlho}

Universidade Federal de Uberlândia (UFU)

Av. João Naves de Ávila, 2121 - Santa Mônica, Uberlândia / MG. Brasil, CEP: 38408-100 